\title{
Scientific Notes
}

\section{Equine infectious anemia affects the athletic performance of equines from the Brazilian Pantanal region}

\author{
Débora Roque de Freitas Andrade ${ }^{(1)}$, Adalgiza Souza Carneiro Rezende ${ }^{(1)}$, Sandra Aparecida Santos ${ }^{(2)}$, \\ Márcia Furlan Nogueira(2), Juliano Martins Santiago( ${ }^{(3)}$, Jéssica Lage ${ }^{(1)}$, Marília Martins Melo(1), \\ Jenner Karlisson Pimenta Reis ${ }^{(1)}$ and Pablo Trigo ${ }^{(4)}$
}

\begin{abstract}
(1)Universidade Federal de Minas Gerais, Campus Pampulha, Avenida Antônio Carlos, no 6.627, CEP 31270-901 Belo Horizonte, MG, Brazil. E-mail: d_roque@live.com, adalgizavetufmg@gmail.com, jessicalage@gmail.com, mariliamartinsmelovet@hotmail.com, jenner@ufmg.br (2)Embrapa Pantanal, Rua 21 de Setembro, no 1.880, Nossa Senhora de Fátima, CEP 79320-900 Corumbá, MS, Brazil. E-mail: sandra.santos@embrapa.br, marcia.furlan@embrapa.br ${ }^{(3)}$ Universidade Federal Rural de Pernambuco, Unidade Acadêmica de Serra Talhada, Avenida Gregório Ferraz Nogueira, s/no, José Tomé de Souza Ramos, CEP 56909-535 Serra Talhada, PE, Brazil. E-mail: jmartinssantiago@yahoo.com.br (4) Universidad Nacional de La Plata, Calle 60 y 118, s/no (1900), Casilla de Correo 296, La Plata, Provincia de Buenos Aires, República Argentina. E-mail: ptrigo@fcv.unlp.edu.ar
\end{abstract}

Abstract - The objective of this work was to evaluate the effects of equine infectious anemia (EIA) on the physical performance of equines from the Brazilian Pantanal region. A total of 16 males were evaluated, divided into two groups: 8 seronegative (G1) and 8 seropositive (G2) for EIA. Two graded exercise tests were carried out before (T1) and after (T2) 42 days of training. Heart rate, lactate concentration, distance covered, and hematocrit level were recorded. In both tests, G1 covered a greater distance. In T2, G2 had lower hematocrit levels and lower speeds reached at different lactate concentrations and heart rates. The athletic performance of the evaluated equines is affected by equine infectious anemia.

Index terms: Brazilian breed, endemic areas, equideoculture, equine infectious anemia, physiology of equine exercise.

\section{Anemia infecciosa equina afeta o desempenho atlético de equinos da região do Pantanal brasileiro}

Resumo - O objetivo deste trabalho foi avaliar o efeito da anemia infecciosa equina (AIE) no desempenho físico de equinos da região do Pantanal brasileiro. Foram avaliados 16 machos, divididos em dois grupos: 8 soronegativos (G1) e 8 soropositivos (G2) para AIE. Dois testes de esforço progressivo foram realizados, antes (T1) e após (T2) 42 dias de treinamento. Foram registrados frequência cardíaca, concentração de lactato, distância percorrida e níveis de hematócrito. Em ambos os testes, o G1 percorreu uma distância maior. No T2, o G2 apresentou menores níveis de hematócrito e menor velocidade obtida a diferentes concentrações de lactato e frequências cardíacas. O desempenho atlético dos equídeos avaliados é afetado pela anemia infecciosa equina.

Termos para indexação: raça brasileira, áreas endêmicas, equideocultura, anemia infecciosa equina, fisiologia do exercício em equinos.

Equine infectious anemia (EIA) is a disease distributed worldwide that affects members of the Equidae family (Craigo \& Montelaro, 2008). Classic cases of EIA can evolve to three distinct clinical phases: acute, chronic, and inapparent carrier. As an inapparent carrier, the animal has no clinical symptoms but becomes a virus carrier and transmitter for life (Cook et al., 2009).
In EIA-affected regions, the disease, which is transmissible and incurable, is an obstacle to the development of equideoculture, specifically for horse owners who depend on the work of these animals and for those interested in genetic breeding improvement, besides restricting the access of this activity to the international market (Almeida et al., 2006). 
In Brazil, considering EIA is currently an incurable disease, the euthanasia of seropositive animals is recommended (Brasil, 2004). However, in regions with a high prevalence of EIA, where husbandry is widespread, such as the Pantanal, this practice would seriously compromise or even halt the activity, which depends on workhorses. Therefore, in endemic areas like this one, the legislation for the prevention and control of EIA allows the isolation of carriers (Brasil, 2004) that continue being used to assist livestock handlers (Silva et al., 2001).

The Pantaneiro horse breed stands out for cattle tending in the Pantanal because of its rusticity and adaptation to the harsh climate conditions of the region - long periods of drought followed by extensive floods -, which other breeds would not survive.

The athletic performance of equines can be evaluated through physical tests performed either on the treadmill or in the field (Boffi, 2007). In the field, heart rate, speed, and blood lactate concentration ([La]) are among the main measurements used to assess the functional performance of a horse. Through [La], it is possible to evaluate physical fitness, as well as to prescribe training intensity and to recommend adaptations to it (Trilk et al., 2002). Horses with greater resistance also show higher V4 speed, reached at [La] of $4 \mathrm{mmol} \mathrm{L}^{-1}$. The heart rate determined in the field can be used to indirectly estimate oxygen uptake and provides additional information on the performance and energy metabolism of the animals (Eaton et al., 1995; Piccione et al., 2013). However, the environmental conditions must be controlled and tests must be standardized (horseman, speed, and location, for example) for reliable results to be obtained (Evans, 2000). The present study's hypothesis is that horses infected with the EIA virus show lower physical performance when herding cattle, compared with uninfected animals.

The objective of this work was to evaluate the effects of equine infectious anemia (EIA) on the physical performance of equines from the Brazilian Pantanal region.

All procedures and animal handling followed the ethical principles adopted by the ethics committee on animal use of Universidade Federal de Minas Gerais, under protocol number 211/2015. A total of 16 male Pantaneiro horses, between 10 and 16 years old, weighing $343.2 \pm 35.3 \mathrm{~kg}$, were evaluated.
After a serological test using the approved agar gel immunodiffusion for EIA and clinical examination, including evaluations of general and body condition, skin turgor, capillary refill time, rectal temperature, blood tests to check for hemoparasites, and digital pulse, the horses were divided into two uniform groups: G1 and G2. G1 contained eight healthy animals, which were negative for EIA, and G2, eight animals that were seropositive for EIA, but without any active clinical symptom. The horses were kept loose on a native pasture in two nearby farms in the Nhecolândia region of Pantanal Matogrossense, Brazil; mineral salt and water were offered ad libitum.

The experiment started in September, in the dry season. The animals were subjected to two field graded exercise tests: $\mathrm{T} 1$, initial test before a 42-day conditioning period; and $\mathrm{T} 2$, final test at the end of the training period. The mean ambient temperature and the mean air relative humidity were 31.5 and $27.4^{\circ} \mathrm{C}$ and 75 and $80 \%$, respectively, in $\mathrm{T} 1$ and $\mathrm{T} 2$.

For the test protocol, after a 10-min warm-up in walk, a horseman, with a weight of $70 \mathrm{~kg}$ and a height of $1.70 \mathrm{~m}$, using a GPS watch, guided each horse through $1,500 \mathrm{~m}$ of a plane grass track, in the following gaits: slow trot, $3.5 \mathrm{~m} \mathrm{~s}^{-1}$; trot, $4.2 \mathrm{~m} \mathrm{~s}^{-1}$; canter, $5.3 \mathrm{~m} \mathrm{~s}^{-1}$; and gallop, $8.2 \mathrm{~m} \mathrm{~s}^{-1}$. During the test, all animals wore the equine RS800CX N GPS heart rate monitor (PolarBrasil, São Paulo, SP, Brazil). It should be pointed out that the horses only started the next step (gait) when their heart rate was equal to or lower than $70 \mathrm{bpm}$. During the test, a blood sample was collected with disposable syringes to estimate [La] using the portable Accutrend Plus System lactate meter (F. Hoffmann-La Roche Ltd., Basal, Switzerland), and heart rate was recorded immediately after each gait mode. Tests were interrupted when [La] and/or heart rate reached values equal to or greater than $4 \mathrm{mmol} \mathrm{L}^{-1}$ and/or $150 \mathrm{bpm}$, respectively. For this reason, not all animals went through the four steps determined in the protocol, i.e., some reached heart rate $>150 \mathrm{bpm}$ and $[\mathrm{La}]>4 \mathrm{mmol} \mathrm{L} \mathrm{L}^{-1}$ before completing all steps. Blood samples were also taken to evaluate hematocrit at 0 , 10, 30, and $60 \mathrm{~min}$ after $\mathrm{T} 1$ and $\mathrm{T} 2$, as well as during resting time.

After this protocol, the physical conditioning of each horse was assessed. For this, during 42 days (T1), all animals worked in alternate days during 1 hour between walk and canter. The speed during canter 
was individualized (monitored by a GPS-wearing horseman), corresponding to the speed the horse reached when its [La] was $3 \mathrm{mmol} \mathrm{L}^{-1}$ or $75 \%$ of $\mathrm{V} 4$, as adapted from Fonseca et al. (2015). In the first three weeks, the training protocol was: $10 \mathrm{~min}$ in walk, $5 \mathrm{~min}$ in canter, $20 \mathrm{~min}$ in walk, $5 \mathrm{~min}$ in canter, and then $20 \mathrm{~min}$ in walk. At the end of the third week of training, the animals were evaluated at the end of the gallop gait, and those that exhibited [La] lower than $4 \mathrm{mmol} \mathrm{L}^{-1}$ had their training intensity increased to: 10 min in walk, $10 \mathrm{~min}$ in canter, $15 \mathrm{~min}$ in walk, $10 \mathrm{~min}$ in canter, and $15 \mathrm{~min}$ in walk.

After 42 days of physical conditioning, horses from G1 and G2 were subjected to the second (T2) graded exercise test in the field, following the same protocol as in T1. It should be noted that, on Sundays, the animals from both groups rested. With the results obtained during the exercise tests, the following simple linear regression equation was used to estimate the speed at which [La] reached 2 (V2), 3 (V3), and $4 \mathrm{mmol} \mathrm{L}^{-1}$ (V4): $\mathrm{y}=\mathrm{a}+\mathrm{bx}$ where $\mathrm{y}$ is velocity $\left(\mathrm{m} \mathrm{s}^{-1}\right)$; and $\mathrm{x}$ is lactate concentration $\left(\mathrm{mmol} \mathrm{L}^{-1}\right)$ or heart rate (bpm). Similarly, speed was measured at the following defined heart rates: 160, 180, and $200 \mathrm{bpm}$. The experimental design was randomized in subdivided plots; each group represented a plot, each test a split-plot, and evaluation times the split-split-plots. The results were subjected to the analysis of variance, and means were compared using the mean.
Before (T1) and after (T2) training, G1 covered a greater distance during the graded exercise test, compared with G2 (Table 1). This result shows the worse performance of EIA-carrier animals, which were fatigued sooner (Cairns, 2006).

In the Pantanal, cattle tending by the Pantaneiro horse can be considered a combination of endurance (aerobic) and high intensity (anaerobic) exercises. Since [La] is a product of the anaerobic glycolytic muscle metabolism, its measurement can provide information on both the horse's aerobic and anaerobic capacity (Ferraz et al., 2008; Allen et al., 2016). The results obtained for [La] showed that there was no significant difference between G1 and G2 in T1 (Table 1). However, in T2, G2 had lower V2, V3, and V4 than G1 (Table 2), indicating a lower aerobic fitness and greater energy contribution by the glycolytic pathway in horses with EIA, probably due to their reduced capacity to carry oxygen because of the decrease in the number of erythrocytes caused by the disease (Issel et al., 2014).

Due to the difficulties in measuring oxygen consumption in the field, heart rate was used as a parameter for the evaluation of cardiovascular function and aerobic metabolism (Allen et al., 2016). The results obtained for heart rate show that there was no significant difference between G1 and G2 before training (Table 1). However, after training, G2 reached the heart rates of 160,180, and $200 \mathrm{bpm}$ at lower speeds, which indicates that the horses from this group

Table 1. Values and standard deviations for speed $\left(\mathrm{m} \mathrm{s}^{-1}\right)$ reached at different blood lactate concentrations and heart rates, as well as distance covered ( $\mathrm{km})$, by seronegative (G1) and seropositive (G2) horses for equine infectious anemia during the graded exercise tests before (test 1) and after (test 2) training ${ }^{(1)}$.

\begin{tabular}{|c|c|c|c|c|}
\hline \multirow[t]{2}{*}{ Variable $^{(2)}$} & \multicolumn{2}{|c|}{ Test 1} & \multicolumn{2}{|c|}{ Test 2} \\
\hline & G1 & $\mathrm{G} 2$ & G1 & $\mathrm{G} 2$ \\
\hline & \multicolumn{4}{|c|}{ Blood lactate } \\
\hline V2 & $3.64 \pm 0.93 \mathrm{a}$ & $2.77 \pm 1.55 \mathrm{a}$ & $4.30 \pm 0.92 \mathrm{a}$ & $2.78 \pm 0.70 \mathrm{~b}$ \\
\hline V3 & $4.58 \pm 0.94 \mathrm{a}$ & $3.70 \pm 1.30 \mathrm{a}$ & $5.04 \pm 0.77 \mathrm{a}$ & $3.78 \pm 0.61 \mathrm{~b}$ \\
\hline \multirow[t]{2}{*}{ V4 } & $5.51 \pm 1.26 \mathrm{a}$ & $4.65 \pm 1.14 \mathrm{a}$ & $5.77 \pm 0.91 \mathrm{a}$ & $4.78 \pm 0.70 \mathrm{~b}$ \\
\hline & \multicolumn{4}{|c|}{ Heart rate } \\
\hline V160 & $5.71 \pm 0.73 \mathrm{a}^{*}$ & $5.40 \pm 1.57 \mathrm{a}$ & $10.30 \pm 3.42 \mathrm{a}^{*}$ & $5.77 \pm 1.71 \mathrm{~b}$ \\
\hline V180 & $6.96 \pm 0.88 \mathrm{a}^{*}$ & $6.35 \pm 1.92 \mathrm{a}$ & $12.98 \pm 4.58 \mathrm{a}^{*}$ & $7.05 \pm 2.34 b$ \\
\hline V200 & $8.20 \pm 1.05 \mathrm{a}^{*}$ & $7.30 \pm 2.28 \mathrm{a}$ & $15.62 \pm 5.79 \mathrm{a}^{*}$ & $8.34 \pm 2.98 \mathrm{~b}$ \\
\hline \multicolumn{5}{|l|}{ Distance covered } \\
\hline Distance covered & $6.10 \pm 0.70 \mathrm{a}$ & $4.66 \pm 1.72 b$ & $6.56 \pm 0.72 \mathrm{a}$ & $4.69 \pm 0.85 b$ \\
\hline
\end{tabular}

${ }^{(1)}$ Means followed by equal letters, in the same line, do not differ significantly by Fisher's test for blood lactate concentration and by Tukey's test for heart rate and distance covered, at 5\% probability. ${ }^{(2)} \mathrm{Blood}$ lactate concentrations: V2, V3, and V4, 2, 3, and $4 \mathrm{mmol} \mathrm{L}^{-1}$, respectively; and heart rates: V160, V180, and V200, 160, 180, and $200 \mathrm{bpm}$, respectively. *Significant between test 1 and test 2 by Tukey’s test, at 5\% probability. 
Table 2. Values and standard deviations for hematocrit (\%) in seronegative (G1) and seropositive (G2) horses for equine infectious anemia at $0,10,30$, and 60 min after tests performed before (T1) and after (T2) training, as well as during resting time $^{(1)}$.

\begin{tabular}{|c|c|c|c|c|c|}
\hline \multirow[t]{2}{*}{ Serology } & \multicolumn{5}{|c|}{ Hematocrit (\%) } \\
\hline & Resting time & $0 \mathrm{~min}$ & $10 \mathrm{~min}$ & $30 \mathrm{~min}$ & $60 \mathrm{~min}$ \\
\hline & \multicolumn{5}{|c|}{ Test performed before training (T1) } \\
\hline Seronegative (G1) & $30.00 \pm 3.33 \mathrm{Ab}$ & $39.12 \pm 4.81 \mathrm{Aa}$ & $33.75 \pm 2.48 \mathrm{Aab}$ & $29.25 \pm 3.05 \mathrm{Bb}$ & $29.12 \pm 2.96 \mathrm{Ab}$ \\
\hline \multirow[t]{2}{*}{ Seropositive (G2) } & $31.00 \pm 2.58 \mathrm{Ab}$ & $38.88 \pm 6.76 \mathrm{Aa}^{*}$ & $35.87 \pm 3.35 \mathrm{Aab}^{*}$ & $32.62 \pm 2.40 \mathrm{Aab}^{*}$ & $30.37 \pm 4.28 \mathrm{Ab}^{*}$ \\
\hline & \multicolumn{5}{|c|}{ Test performed after training (T2) } \\
\hline Seronegative (G1) & $27.38 \pm 2.87 \mathrm{Ac}$ & $42.12 \pm 2.53 \mathrm{Aa}$ & $34.87 \pm 3.44 \mathrm{Aab}$ & $31.00 \pm 2.56 \mathrm{Abc}$ & $30.50 \pm 5.92 \mathrm{Abc}$ \\
\hline Seropositive (G2) & $30.00 \pm 4.34 \mathrm{Aab}$ & $35.88 \pm 4.99 \mathrm{Ba}^{*}$ & $30.75 \pm 2.91 \mathrm{Bab}^{*}$ & $27.12 \pm 3.39 \mathrm{Bb}^{*}$ & $26.25 \pm 2.31 \mathrm{Bb}^{*}$ \\
\hline
\end{tabular}

(1)Means followed by different letters, lowercase in the lines and uppercase in the columns, indicate significant differences between evaluation times and between experimental groups in each physical test, respectively, by Tukey's test, at 5\% probability. *Significant between test 1 and test 2 by Tukey's test, at $5 \%$ probability.

were less physically conditioned than those from G1. When equines are more physically conditioned, they are capable of performing exercises at higher speeds before reaching maximum heart rate, and speed increases at 150 and $200 \mathrm{bpm}$ (Evans, 2000). These results also shows the positive influence of training on the performance of the horses from G1, which had a significant gain in speed at 160, 180, and $200 \mathrm{bpm}$ from $\mathrm{T} 1$ to $\mathrm{T} 2$, whereas those from $\mathrm{G} 2$ did not show any significant improvement.

A trained equine must be capable of reaching a certain speed at a lower heart rate than the one before undergoing training (Babusci \& López, 2007). Training produces adaptive alterations in the heart rate that can be used to assess improvement in performance due to exercise (Bayly \& Kline, 2007; Boffi, 2007;). In the present study, 42 days of training were not capable of improving the heart rate of EIA-seropositive horses (G2), which may be explained by their difficulty in transporting oxygen.

The obtained results indicate that, at rest, animals from G1 and G2 presented similar hematocrit in both tests (Table 2). However, after training, in T2, G2 had lower levels $(\mathrm{p}<0.05)$ at all times evaluated, which could be attributed to the physical exertion of the horses of this group during the test and also to the greater distance covered by G1 (Table 1). In T1, this difference was not observed.

In conclusion, the shorter distance covered by EIAseropositive animals, as well as their lower hematocrit values, lactate indexes $\left(2,3\right.$, and $\left.4 \mathrm{mmol} \mathrm{L}^{-1}\right)$, and heart rates $(160,180$, and $200 \mathrm{bpm})$, confirms their lower work capacity compared with their seronegative counterpart.

\section{Acknowledgments}

To Conselho Nacional de Desenvolvimento Científico e Tecnológico (CNPq), to Coordenação de Aperfeiçoamento de Pessoal de Nível Superior (Capes), and to Fundação de Amparo à Pesquisa do Estado de Minas Gerais (Fapemig), for scholarships granted; and to Empresa Brasileira de Pesquisa Agropecuária (Embrapa, 02.12.01.030.00.03), for financial support.

\section{References}

ALLEN, K.J.; VAN ERCK-WESTERGREN, E.; FRANKLIN, S.H. Exercise testing in the equine athlete. Equine Veterinary Education, v.28, p.89-98, 2016. DOI: 10.1111/eve.12410.

ALMEIDA, V.M.A.; GONÇALVES, V.S.P.; MARTINS, M.F.; HADDAD, J.P.A.; DIAS, R.A.; LEITE, R.C.; REIS, J.K.P. Anemia infecciosa eqüina: prevalência em eqüídeos de serviço em Minas Gerais. Arquivo Brasileiro de Medicina Veterinária e Zootecnia, v.58, p.141-148, 2006. DOI: 10.1590/S010209352006000200001.

BABUSCI, M.; LÓPEZ, E.F. Sistema cardiovascular. In: BOFFI, F.M. Fisiología del ejercicio en equinos. Buenos Aires: InterMédica, 2007. p.123-132.

BAYLY, W.; KLINE, K.A. Hematología y bioquímica. In: BOFFI, F.M. Fisiología del ejercicio en equinos. Buenos Aires: InterMédica, 2007. p.145-151.

BOFFI, F.M. Fisiología del ejercicio en equinos. Inter-Médica: Buenos Aires, 2007.

BRASIL. Ministério da Agricultura, Pecuária e Abastecimento. Instrução Normativa $n^{\circ} 45$, de 15 de junho de 2004. [Aprova as Normas para a Prevenção e o Controle da Anemia Infecciosa Eqüina -A.I.E.].DiárioOficialdaUnião,7jul.2004.Seção 1,p.7-9.Available at: $\quad<\mathrm{http}$ ://pesquisa.in.gov.br/imprensa/jsp/visualiza/index. jsp?data $=07 / 07 / 2004 \&$ jornal $=1 \&$ pagina $=7 \&$ total Arquivos $=116>$. Accessed on: Sept. 102014.

Pesq. agropec. bras., Brasília, v.53, n.10, p.1184-1188, Oct. 2018 DOI: $10.1590 / \mathrm{S} 0100-204 \mathrm{X} 2018001000012$ 
CAIRNS, S.P. Lactic acid and exercise performance: culprit or friend? Sports Medicine, v.36, p.279-291, 2006. DOI: 10.2165/00007256-200636040-00001.

COOK, R.F.; COOK, S.J.; ISSEL, C.J. Equine infectious anemia. In: MAIR, T.S.; HUTCHINSON, R.E. (Ed.). Infectious diseases of the horse. Fordham: Equine Veterinary Journal, 2009. p.56-71.

CRAIGO, J.K.; MONTELARO, R.C. Equine infectious anemia virus. In: MAHY, B.W.J.; VAN REGENMMORTEL, M.H.V. (Ed.). Encyclopedia of Virology. $3^{\text {rd }}$ ed. 2008. v.2, p.167-174. DOI: 10.1016/B978-012374410-4.00395-2.

EATON, M.D.; EVANS, D.L.; HODGSON, D.R.; ROSE, R.J. Effect of treadmill incline and speed on metabolic rate during exercise in Thoroughbred horses. Journal of Applied Physiology, v.79, p.951-957, 1995. DOI: 10.1152/jappl.1995.79.3.951.

EVANS, D.L. Training and fitness in athletic horses. Barton: Rural Industries Research and Development Corporation, 2000.

FERRAZ, G.C.; D'ANGELIS, F.H.F.; TEIXEIRA-NETO, A.R.; FREITAS, E.V.V.; LACERDA-NETO, J.C.; QUEIROZ-NETO, A. Blood lactate threshold reflects glucose responses in horses submitted to incremental exercise test. Arquivo Brasileiro de Medicina Veterinária e Zootecnia, v.60, p.256-259, 2008. DOI: 10.1590/S0102-09352008000100035.

FONSECA, M.G.; REZENDE, A.S.C.; JORDÃO, L.R.; LAGE, J.; ALMEIDA, M.L.M.; ANDRADE, J.M.; QUEIROZ NETO,
A.; FERRAZ, G.C. Chromium or L-carnitine supplementation during an aerobic conditioning program mildly modified the energy metabolism biomarker response in Mangalarga Marchador fillies. Livestock Science, v.177, p.165-174, 2015. DOI: 10.1016/j. livsci.2015.03.014.

ISSEL, C.J.; COOK, R.F.; MEALEY, R.H.; HOROHOV, D.W. Equine infectious anemia in 2014: live with it or eradicate it? Veterinary Clinics of North America: Equine Practice, v.30, p.561-577, 2014. DOI: 10.1016/j.cveq.2014.08.002.

PICCIONE, G.; MESSINA, V.; BAZZANO, M.; GIANNETTO, C.; FAZIO, F. Heart rate, net cost of transport, and metabolic power in horse subjected to different physical exercises. Journal of Equine Veterinary Science, v.33, p.586-589, 2013. DOI: 10.1016/j.jevs.2012.09.010.

SILVA, R.A.M.S.; ABREU, U.G.P. de; BARROS, A.T.M. de. Anemia infecciosa equina: epizootiologia, prevenção e controle no Pantanal. Corumbá: Embrapa Pantanal, 2001. 30p. (Embrapa Pantanal. Circular técnica, 29).

TRILK, J.L.; LINDNER, A.J.; GREENE, H.M.; ALBERGHINA, G.D.; WICKLER, S.J. A lactate-guided conditioning programme to improve endurance performance. Equine Veterinary Journal, v.34, p.122-125, 2002. DOI: 10.1111/j.2042-3306.2002. tb05403.x.

Received on May 16, 2017 and accepted on January 4, 2018 